\title{
When less is more: the changing paradigm in critical care medicine
}

\section{Gentle S Shrestha}

Critical care medicine is one of the fastest growing specialties. In the recent decades, the process of care and outcome of patients has improved. It looks more attributable to greater recognition and removal of harmful practices and iatrogenicity, rather than to novel pharmacological or mechanical interventions. ${ }^{1,2}$ It complies with one of the fundamental principles of ethics in critical care nonmaleficence, the duty of health care professionals to avoid harm. ${ }^{3}$ The historical concept of "Primum non nocere" or first do no harm, by Hippocrates, appears crucial in daily critical care practice. ${ }^{4-6}$ As we manage the critically ill patients, we often may find our patients not improving despite the best practice and application of all existing understandings and evidences. ${ }^{7}$ It often reminds me of the aphorism "to cure sometimes, to relieve often, to comfort always". ${ }^{8}$ The risk and benefit of the proposed treatments need to be weighed before deciding to treat, despite significant risks are employed. ${ }^{6}$ Studies in the past decades have challenged many conventional wisdoms and taught us the lessons that overuse or misuse of drugs or devices, and/or excessively striving for physiological or biochemical normality, may provide short term gains but at the expense of longer-term detriments. ${ }^{9}$ Thus the concept of "less is more" is evolving in critical care medicine.

I have tried to mention some, among many interventions, for which less has been shown to be associated with a better outcome. In patients with acute lung injury and acute respiratory distress syndrome, mechanical ventilation with a lower tidal volume of $6 \mathrm{ml}$ per kilogram of predicted body weight or less, keeping the plateau pressure of $30 \mathrm{~cm}$ of water or less, when compared to traditional ventilation treatment involving a tidal volume of $12 \mathrm{ml}$ per kilogram of predicted body weight and the plateau pressure of $50 \mathrm{~cm}$ of water or less is associated with decreased mortality and increase in the number of days without ventilator use. ${ }^{10,11}$ The decrease in mortality is probably attributable to reduction of ventilator-induced lung injury, by avoiding the iatrogenic harm of conventional ventilation strategies. ${ }^{12}$

While aggressive fluid resuscitation, early in the course of sepsis is beneficial, liberal fluid administration later in the course may be deleterious. ${ }^{13}$ Conservative strategies of fluid management may be beneficial in patients with acute lung injury in terms of improved lung function and shortened duration of mechanical ventilation and intensive care without increasing non-pulmonary organ failures. ${ }^{14}$ In critically ill patients, positive cumulative fluid balance is associated with intra-abdominal hypertension and worst outcome. In patients not transgressing spontaneously from Ebb to Flow phases of shock, late conservative fluid management and late goal directed de-resuscitation can be beneficial. ${ }^{15,16}$
Following the initial extensive use of pulmonary artery catheter to guide management of critically ill patients, its use has progressively declined considering the invasiveness of the procedure for insertion and lack of conferred benefits. ${ }^{17,18}$ Less invasive and non-invasive devices are emerging as possible surrogates for cardiac output monitoring. ${ }^{19}$ Besides hemodynamic monitoring, evidence is also growing in favour of other less invasive monitoring modalities..$^{20-22}$

Transfusion of blood and blood products has been associated with multiple complications including transfusion related acute lung injury (TRALI) and transfusion associated circulatory overload (TACO). ${ }^{23,24}$ Evidence is growing in favor of restricted transfusion rather than liberal transfusion..$^{25}$ It does seem true for critically ill adult patients, ${ }^{26}$ pediatric patients, ${ }^{27}$ patients with septic shock, ${ }^{28}$ patients with acute upper gastrointestinal bleeding, ${ }^{29}$ and in patients with myocardial infarction. ${ }^{30}$

Following the landmark paper by Van den Berghe et al, which showed significant reduction in morbidity and mortality among surgical critically ill patients, who underwent intensive insulin therapy, there was a paradigm shift in practice towards tight glycemic control in critically ill patients. ${ }^{31}$ However, subsequent studies and meta-analysis failed to replicate similar results. Moreover, there was increased risk of hypoglycemia in patients undergoing intensive insulin therapy. ${ }^{32-34}$ The potential harm of tight glycemic control in criticall ill patients, was shown in the large international randomized trial - the NICE-SUGAR study. The blood sugar target of $180 \mathrm{mg}$ or less per deciliter resulted in lower mortality than did a target of 81 to $108 \mathrm{mg}$ per deciliter. ${ }^{35}$

In patients with ventilator associated pneumonia, with the possible exception of those developing nonfermenting gram-negative bacillus infection, a shorter duration (7-8 days) of appropriate antibiotic therapy was comparable to prolonged course (10 to 15 days) in terms of effectiveness. ${ }^{36,37}$ Procalcitonin guided strategy to reduce the duration of antibiotic treatment can safely reduce the duration of antibiotic exposure and potentially minimize the emergence of multidrug-resistant bacteria in intensive care units. ${ }^{38}$ In patients with severe sepsis and septic shock, de-escalation of empirical antibiotic therapy, defined as discontinuation of an antimicrobial agent or change of antibiotic to one with a narrower spectrum once culture reports are available, is associated with lower mortality. ${ }^{39}$

However, "less is more" is not a general rule. Sometimes, we find "more is more" in intensive care. Early physical and occupational rehabilitation in critically ill, mechanically ventilated pateints is associated with better outcome. ${ }^{40}$ Goal 
directed therapy, aiming at augmenting oxygen delivery index is found to be beneficial in high-risk patients undergoing major surgery. ${ }^{41,42}$ Effective antimicrobial administration within first hour of septic shock is associated with improved survival. ${ }^{43,44}$

Considering the fact that preventable harm is not uncommon in ICU, ${ }^{45,46}$ adapting a more cautious approach while managing the vulnerable critically ill patients, ${ }^{5,47}$ respecting the concept of "Primum non nocere", can be associated with improved outcome. It would be prudent to keenly and closely follow the results of new trials and to individualize the strategies of intervention for individual patients. ${ }^{6}$ Today, and for the centuries to come, the role of an intensivist can often appear to support the physiology of a patient while waiting for the mother nature to heal, as mentioned by Oliver Wendell Holmes - "the art of medicine consists of amusing the patient until nature cures the disease". ${ }^{48}$ That is when less actually may mean more for our patients.

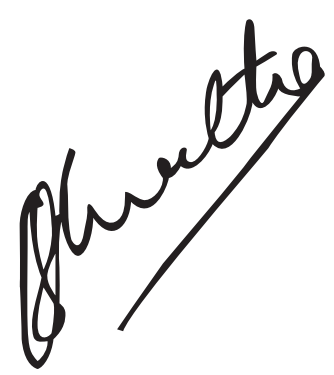

Dr. Gentle Sunder Shrestha

MD, FACC, EDIC, FCCP

Neuro-Intensivist \& Anaesthesiologist

Department of Anaesthesiology

Tribhuvan University Teaching Hospital

Maharajgunj, Kathmandu, Nepal

Email: gentlesunder@hotmail.com

\section{References:}

1. Vincent JL. Critical care - where have we been and where are we going? Crit Care 2013;17 Suppl 1:S2.

2. Singer M, Glynne P. Treating critical illness: the importance of first doing no harm. PLoS Med 2005;2:e167.

3. Bledsoe TA, Levy MM. Basic ethical principles in critical care. In: Vincent JL, Abraham E, Moore FA, Kochanek PM, Fink MP, editors. Textbook of critical care. $6^{\text {th }}$ ed. United States of America: Saunders; 2011. p.1573-5.

4. Orlowski JP. Ethical principles in critical care medicine. Crit Care Med 1986;2:13-25.

5. Kox M, Pickkers P. "Less is more" in critically ill patients: not too intensive. JAMA Intern Med 2013;173:1369-72.

6. Festic E, Gajic O. When less is more in the intensive care unit; lessons learned. Bosn J Basic Med Sci 2009;9 Suppl 1:54-8.

7. Da Sylva NP. To cure sometimes, to relieve often, to comfort always. Can Med Assoc J 1985;132:607.

8. Cayley WE Jr. Comfort always. Fam Pract Manag 2006;13:74.
9. Singer M. The key advance in the treatment of sepsis in the last 10 years...doing less. Crit Care 2006;10:22.

10. Ventilation with lower tidal volumes as compared with traditional tidal volumes for acute lung injury and the acute respiratory distress syndrome. The Acute Respiratory Distress Syndrome Network. N Engl J Med 2000;342:1301-8.

11. Tonelli AR, Zein J, Adams J, Ioannidis JP. Effects of interventions on survival in acute respiratory distress syndrome: an umbrella review of 159 published randomized trials and 29 meta-analyses. Intensive Care Med 2014;40:769-87.

12. Slutsky AS, Ranieri VM. Ventilator-induced lung injury. N Engl J Med 2013;369:2126-36.

13. Durairaj L, Schmidt GA. Fluid therapy in resuscitated sepsis: less is more. Chest 2008;133:252-63.

14. Wiedemann HP, Wheeler AP, Bernard GR, Thompson BT, Hayden $\mathrm{D}$, deBoisblanc $\mathrm{B}$, et al. Comparison of two fluid-management strategies in acute lung injury. N Engl J Med 2006;354:2564-75.

15. Malbrain ML, Marik PE, Witters I, Cordemans C, Kirkpatrick AW, Roberts DJ, et al. Fluid overload, de-resuscitation, and outcomes in critically ill or injured patients: a systematic review with suggestions for clinical practice. Anaesthesiol Intensive Ther 2014;46:361-80.

16. Chen $\mathrm{C}$, Kollef MH. Targeted fluid minimization following initial resuscitation in septic shock: A pilot study. Chest 2015;148:1462-9.

17. Shah MR, Hasselblad V, Stevenson LW, Binanay C, O'Connor $\mathrm{CM}$, Sopko G, et al. Impact of pulmonary artery catheter in critically ill patients: meta-analysis of randomized clinical trials. JAMA 2005;294:1664-70.

18. Marik PE. Obituary: pulmonary artery catheter 1970 to 2013 . Ann Intensive Care 2013;3:38.

19. Marik PE. Noninvasive cardiac output monitors: a state-of the-art review. J Cardiothorac Vasc Anesth 2013;27:121-34.

20. Kasotakis G, Michailidou M, Bramos A, Chang Y, Velmahos G, Alam $\mathrm{H}$, et al. Intraparenchymal vs extracranial ventricular drain intracranial pressure monitors in traumatic brain injury: less is more? J Am Coll Surg 2012;214:950-7.

21. Dubourg J, Javouhey E, Geeraerts T, Messerer M, Kassai B. Ultrasonography of optic nerve sheath diameter for detection of raised intracranial pressure: a systematic review and meta-analysis. Intensive Care Med 2011;37:1059-68.

22. Maissan IM, Dirven PJ, Haitsma IK, Hoeks SE, Gommers D, Stolker RJ. Ultrasonographic measured optic nerve sheath diameter as an accurate and quick monitor for changes in intracranial pressure. J Neurosurg 2015;123:743-7.

23. Gajic $\mathrm{O}$, Moore SB. Transfusion-related acute lung injury. Mayo Clin Proc 2005;80:766-70.

24. Eder AF, Chambers LA. Noninfectious complications of blood transfusion. Arch Pathol Lab Med 2007;131:708-18.

25. Holst LB, Petersen MW, Haase N, Perner A, Wetterslev J. Restrictive versus liberal transfusion strategy for red blood cell transfusion: systematic review of randomised trials with meta-analysis and trial sequential analysis. BMJ 2015;350:h1354.

26. Hebert PC, Wells G, Blajchman MA, Marshall J, Martin C, Pagliarello G, et al. A multicenter, randomized, controlled clinical trial of transfusion requirements in critical care. Transfusion requirements in critical care investigators, Canadian Critical Care Trial Group. N Engl J Med 1999;340:409-17.

27. Lacroix J, Hebert PC, Hutchinson JS, Hume HA, Tucci M, Ducruet $\mathrm{T}$, et al. Transfusion strategies for patients in pediatric intensive care units. N Engl J Med 2007;356:1609-19. 
28. Holst LB, Haase N, Wetterslev J, Wernerman J, Guttormsen AB, Karlsson S, et al. Lower versus higher hemoglobin thershold for transfusion in septic shock. N Engl J Med 2014;371:1381-91.

29. Villanueva C, Colomo A, Bosch A, Concepcion M, Hernandez-Gea $\mathrm{V}$, Aracil C, et al. Transfusion strategies for acute upper gastrointestinal bleeding. N Engl J Med 2013;368:11-21.

30. Chatterjee S, Wetterslev J, Sharma A, Lichstein E, Mukherjee D. Association of blood transfusion with increased mortality in myocardial infarction: a meta-analysis and diversity-adjusted study sequential analysis. JAMA Intern Med 2013;173:132-9.

31. van den Berghe G, Wouters P, Weekers F, Verwaest C, Bruyninckx $\mathrm{F}$, Schetz $\mathrm{M}$, et al. Intensive insulin therapy in critically ill patients. N Engl J Med 2001;345:1359-67.

32. Brunkhorst FM, Engel C, Bloos F, Meier-Hellmann A, Ragaller M, Weiler $\mathrm{N}$, et al. Intensive insulin therapy and pentastarch resuscitation in severe sepsis. N Engl J Med 2008;358:125-39.

33. Wiener RS, Wiener DC, Larson RJ. Benefits and risks of tight glucose control in critically ill adults: a meta-analysis. JAMA 2008;300:933-44.

34. Arabi YM, Dabbagh OC, Tamim HM, Al-Shimemeri AA, Memish $\mathrm{ZA}$, Haddad $\mathrm{SH}$, et al. Intensive versus conventional insulin therapy: a randomized controlled trial in medical and surgical critically ill patients. Crit Care Med 2008;36:3190-7.

35. Finfer S, Chittock DR, Su SY, Blair D, Foster D, Dhingra V, et al. Intensive versus conventional glucose control in critically ill patients. N Engl J Med 2009;360:1283-97.

36. Chastre J, Wolff M, Fagon JY, Chevret S, Thomas F, Wermert D, et al. Comparison of 8 vs 15 days of antibiotic therapy for ventilator-associated pneumonia in adults: a randomized trial. JAMA 2003;290:2588-98

37. Pugh R, Grant C, Cooke RP, Dempsey G. Short-course versus prolonged-course antibiotic therapy for hospital-acquired pneumonia in critically ill adults. Cochrane Database Syst Rev 2011;10:CD007577.

38. Bouadma L, Luyt CE, Tubach F, Cracco C, Alvarez A, Schwebel C, et al. Use of procalcitonin to reduce patients' exposure to antibiotics in intensive care units (PRORATA trial): a multicentre randomised controlled trial. Lancet 2010;375:463-74.

39. Garnacho-Montero J, Gutierrez-Pizarraya A, Escoresca-Ortega A, Crocia-Palomo Y, Fernandez-Delgado E, Herrera-Melero I, et al.
De-escalation of empirical therapy is associated with lower mortality in patients with severe sepsis and septic shock. Intensive Care Med 2014;40:32-40.

40. Schweickert WD, Pohlman MC, Pohlman AS, Nigos C, Pawlik AJ, Esbrook CL, et al. Early physical and occupational therapy in mechanically ventilated, critically ill patients: a randomized controlled trial. Lancet 2009;373:1874-82.

41. Pearse R, Dawson D, Fawcett J, Rhodes A, Grounds RM, Bennett ED. Early goal-directed therapy after major surgery reduces complications and duration of hospital stay. A randomized, controlled trial. Crit Care 2005;9:R687-93.

42. Cecconi M, Corredor C, Arulkumaran N, Abuella G, Ball J, Grounds RM, et al. Clinical review: Goal-directed therapy-what is the evidence in surgical patients? The effect on different risk groups. Crit Care 2013;17:209.

43. Kumar A, Roberts D, Wood KE, Light B, Parrillo JE, Sharma S, et al. Duration of hypotension before initiation of effective antimicrobial therapy is the critical determinant of survival in human septic shock. Crit Care Med 2006;34:1589-96.

44. Dellinger RP, Levy MM, Rhodes A, Annane D, Gerlach H, Opal SM, et al. Surviving sepsis campaign: international guidelines for management of severe sepsis and septic shock: 2012. Crit Care Med 2013;41:580-637.

45. Cullen DJ, Sweitzer BJ, Bates DW, Burdick E, Edmondson A, Leape LL. Preventable adverse drug events in hospitalized patients: a comparative study of intensive care and general care units. Crit Care Med 1997;25:1289-97.

46. Larsen GY, Donaldson AE, Parker HB, Grant MJ. Preventable harm occuring to critically ill children. Pediatr Crit Care Med 2007;8:331-6.

47. Shrestha GS, Khanal A, Paudel S. Avoiding iatrogenic harm by integrating physical examination findings with a point-of-care lung ultrasonography. Indian J Crit Care Med 2015;19:243-4.

48. Bolton-Maggs PH, Dickerhoff R, Vora AJ. The nontreatment of childhood ITP (or "the art of medicine consists of amusing the patient until nature cures the disease"). Semin Thromb Hemost 2001;27:269-75 